\title{
Centenary of the birth of Professor Antonio Branco Lefèvre (1916-1981)
}

Centenário de nascimento do Professor Antonio Branco Lefèvre (1916-1981)

Maria Joaquina Marques-Dias', Umbertina Conti Reed ${ }^{1}$

1 Universidade de São Paulo, Faculdade de Medicina, Departamento de Neurologia, Disciplina de Neurologia Infantil, São Paulo SP, Brasil.

Correspondence:

Umbertina Conti Reed;Av. Dr. Eneas de Carvalho Aguiar, 25/ sala 5131; 5403-900 São Paulo SP, Brasil;

E-mail:umbertina.reed@hc.fm.usp.br Conflict of interest:

There is no conflict of interest to declare.

Received 02 September 2016 Received in final form 04 October 2016 Accepted 10 October 2016

\section{(cc) BY}

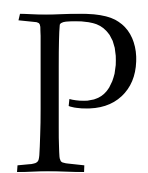

rofessor Antonio Branco Lefèvre graduated from the School of Medicine of the University of São Paulo (FMUSP) in 1941. He then studied psychology at the School of Philosophy of the University of Brasil (current Federal University of Rio de Janeiro), working under the supervision of Professor André Ombredane to explore the subject of child neurology, as shown at the beginning of the 1950s through his doctoral and associate professor dissertations, respectively: "Contribuição para o estudo da patologia da afasia em crianças" (Contribution towards studying the pathology of aphasia among children) and "Contribuição para padronização do exame neurológico do recém-nascido normal" (Contribution towards standardization of the neurological examination for normal newborns).

Together with Professor S. Krinski and other colleagues in the 1960s, Professor Antonio Branco Lefèvre founded the Brazilian Association for Neurology, Child Psychiatry and Related Professions (ABENEPI), a pioneering association in Brazil that to this day still brings together professionals in the fields of neurology and child psychiatry. In the 1970s, he actively participated in the creation of the International Child Neurology Association (ICNA), of which he was vice-president twice (1975 and 1979), and in 1973, he was elected President of the Latin American Child Neurology Society.

Professor Lefèvre was a pioneer in teaching new professionals in the field of child neurology. Together with Professor A. Diament and Dr. Maria Valente, he created a training center in the Department of Neurology of FMUSP. At the beginning of the 1970s, through great effort, this center acquired official credentials for providing medical residency in this specialty, with two years of training.

However, Professor Lefèvre never abandoned his interest in the topic of aphasia, with which he formally began his teaching career and his involvement in discussions in the field of neurosciences. Thus, at the end of the 1970s and just before his death, he created a pioneering study group for upper nerve functions within the Department of Neurology. This acted as a guiding beacon for those whom he left behind, who sought to develop the group over subsequent years. What is interesting to note is that Professor Lefèvre independently anticipated the great swell of neuroscience development with wide national and international impact that has taken place since then.

All of those who had the privilege of knowing Professor Lefèvre could sense his extensive cultural aesthetics, not only in medical terms but also in the form of literary, musical, political and social culture, as well as his profound knowledge and respect for human beings. Despite his vast knowledge, day-to-day contact with him, whether through care, teaching or research activities, was extremely easy. No one felt intimidated by being in the presence of such a renowned professor. Professor Lefèvre knew how to speak with the same simplicity, wisdom and kindness to the families of his patients, to interns or to first-year residents who had just arrived at the ward. He would give them the same respect and attention that he would demonstrate towards his peers and other titular professors. Everyone could understand and admire the precision and clarity of his discourse. His personality made him inherently a man who spoke his mind, never omitting his point of view and, in the same way, he enjoyed listening to other opinions, always humbly and respectfully, while offering stimulation and encouragement towards carrying on and facing up to the inherent difficulties of acting within the field of neuropediatrics.

In conclusion, we are sure that all healthcare services that train child neurologists in Brazil that originated through the efforts of the disciples of Antonio Branco Lefèvre will keep the memory of this man alive among young specialists who will follow us, in memory of the man who is considered to be the father of child neurology in Brazil. 
